\title{
3D プリンタ用短繊維強化再生フィラメントの超音波検査
}

和田 明浩*1, 早稲田一嘉*2, 中山颯太郎*3, 中田祥太郎*3

(2019 年 2 月 28 日受付)

\section{Ultrasonic Testing of Short-fiber Reinforced Reproduction Filaments for 3D Printers}

\begin{abstract}
Akihiro WAdA, ${ }^{* 1}$ Kazuyoshi WASEdA, ${ }^{* 2}$ Sotaro NAKAyAma*3 and Shotaro NAKATA*3
\end{abstract}
(Received February 28, 2019)

\begin{abstract}
In this study, ultrasonic testing equipment is developed to evaluate 3D-printer filaments, particularly short-fiber reinforced reproduction filaments. Recently, 3D printers based on fused deposition modeling (FDM) using thermoplastics have become popular because of the simplicity and relatively low cost. In addition, filaments containing carbon or glass fibers have also been developed to improve the mechanical properties of products. In 3D printers using reproduced filaments, the quality of the filament affects the reliability of the products, particularly in the case of fiber-reinforced filaments. In the equipment developed for this study, ultrasonic waves that passed through the target filament along the longitudinal direction were measured, and the physical properties of the filament were predicted based on wave propagation velocity. To improve the accuracy of the velocity measurement, the Akaike information criterion (AIC) was introduced to detect the wave arrival time of signals. In addition, a finite difference time domain simulation was conducted to confirm the validity of the ultrasonic inspection. It was determined that change in velocity in ultrasonic waves can be used as an index of filament degradation.
\end{abstract}

Key words: Composite material, Nondestructive inspection, Ultrasonic inspection, Filament, AIC

\section{1. 緒}

\section{言}

3D-CAD データから 3 次元造形物を作製する $3 \mathrm{D}$ プリ ンティング技術は，材料加工に関する専門知識が必要な く，手軽に複雑形状を形成できることから普及が進んで おり, 研究も活発に行われている ${ }^{1,2)}$. 従来は試作品を作 製するラピッドプロトタイピングの位置づけであった が, 3D プリンタ造形品の品質向上に伴い, 実製品を製造 する付加製造技術へと進歩しつつある. 特に, 熱溶解積

*1,*2 神戸市立工業高等専門学校機械工学科(651-2194 兵 庫県神戸市西区学園東町 8-3)

Department of Mechanical Engineering, Kobe City College of Technology, 8-3, Gakuenhigashimachi, Nishi-ku, Kobe 651-2194, Japan

*1 教授 Professor, *2 准教授 Associate Professor

*3 神戸市立工業高等専門学校専攻科機械システム工学 専攻（651-2194 兵庫県神戸市西区学園東町 8-3)

Advanced Course of Mechanical Systems Engineering, Kobe City College of Technology, 8-3, Gakuenhigashi-machi, Nishi-ku, Kobe 651-2194, Japan
層方式の 3D プリンタは導入コストが低いため普及して いるが，この方式で多用される ABSや PLA のフィラメ ントを用いて成形された造形物は実用部品とするには強 度・剛性が不十分な場合が多い。この問題を解消するた め, 炭素繊維やガラス䋊維などの強化繊維を含有したフ イラメントが研究・開発されている.

繊維強化フィラメントを強化繊維の形態で分類する と, 長䋊維含有フィラメントと短䋊維含有フィラメント の 2 種に分類される. 長繊維を用いる方式として，ノズ ルヘッド部で連続繊維と樹脂フィラメントを一体化して 繊維含有フィラメントを形成しながら一筆書きの要領で 積層造形していく方式 ${ }^{3)}$ や, 繊維に樹脂を予備含浸させ た中間基材にノズルヘッド部で追加樹脂を供給する方 式4) が研究されており, 強度・剛性の大幅な向上が可能 であることが報告されているが, 現時点では装置の開発 段階にあり, 解決すべき課題も多い. 一方, 短繊維含有 フィラメントは市販されているものもあり, 既存の 3D プリンタでそのまま使用できるという利点がある. 短繊 維を用いた場合, 強度・剛性の向上という観点からは長 
䋊維に比べ劣るが，成形性に優れることから実用性が高 いと考えられる。しかし, 短繊維含有フィラメントを用 いた場合，フィラメント内の強化繊維の配向や分布状態 が $3 \mathrm{D}$ プリンタ成形品の品質に影響を与えることが懸念 される．特に，経済性の観点から最近注目を集めている フィラメントの再生を考えた場合，再生によるフィラメ ントの劣化状態を把握しておく必要性がある．3D プリ ンタ用フィラメントのオンライン検査装置を開発し，不 良区間を排除する機構を取り付けることで $3 \mathrm{D}$ プリンタ 成形品の品質向上が期待できる.

本研究では, 樹脂単体フィラメントに加えて, 炭素短 繊維を含有させた繊維強化フィラメントを評価対象に し，フィラメント再生による材料劣化を超音波で非破壊 検査することを試みた。実験では，フィラメント長手方 向に伝播する超音波の伝播速度を実測するとともに，フ イラメント内を伝播する超音波のシミュレーションを行 い，実測結果の妥当性の検証を行った。また，超音波伝 播速度の計測精度向上を目的として, 統計デー夕処理に 用いられる赤池情報量基準 (AIC) に基づく波形到達時間 の判定を試みた。

\section{2. フィラメントの再生による劣化特性}

\section{1 供 試 材}

熱溶解積層方式は，プリンタヘッド部でフィラメント を加熱溶融させてノズル部から押し出しながら積層造形 する方式のため，造形時の高温状態から室温まで冷却さ れる過程で熱収縮が生じる。このため, 造形温度は低温 であることが望ましく，比較的融点の低い PLA や ABS が多用されている。しかし，これらの樹脂は剛性が低い ため，造形品を実製品として使用するには適さず，試作 品の作製が主流となっている. 現在, PLA に炭素繊維を 含有させた繊維強化フィラメントが開発・市販されてい る。また，軽量で勒性や耐薬品性に優れながらも熱収縮 が大きいため $3 \mathrm{D}$ プリンタに適さないとされてきた $\mathrm{PP}$ においても炭素繊維を含有させて大幅な熱収縮抑制が可 能となり，炭素繊維強化 PP フィラメントが開発・市販 されている，本研究では，吸湿による物性の変化が少な く, 繊維含有による影響を評価しやすいと考えられる PP を評価対象とし，武藤工業(株)製の PP フィラメン 卜（直径 $1.75 \mathrm{~mm}$ ) および，キョーラク(株)製の炭素繊 維強化 $\mathrm{PP}$ フィラメント $(\mathrm{PP} / \mathrm{CF}$, 直径 $1.75 \mathrm{~mm})$ を評 価対象として, 繊維の有無による再生フィラメント劣化 特性を調査した。

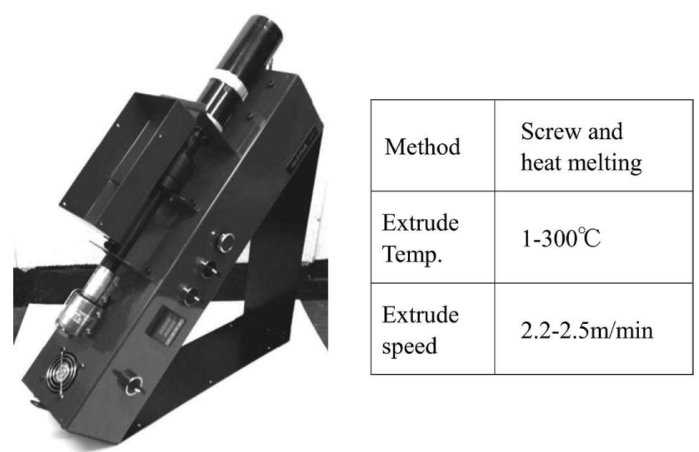

Fig. 1 Photograph of filament reproduction equipment.

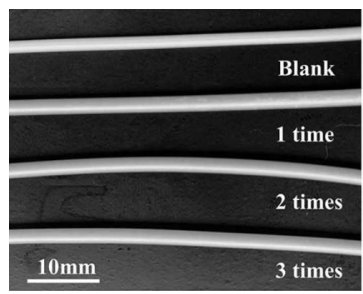

(a) PP filament

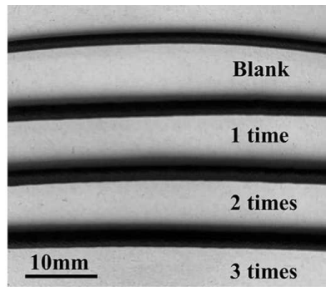

(b) $\mathrm{PP} / \mathrm{CF}$ filament
Fig. 2 Photographs of blank and reproduced filaments.

\section{2 フィラメントの再生および観察}

Fig. 1 に本実験で使用したフィラメント再生機 (Noztek Pro Filament Extruder) の外観と主な仕様を示す. 本 再生機はペレット状の原料を投入することで，加熱しな がらスクリューによってフィラメントを押し出し成形す る機構となっている。本来は造形時に発生する余剒部分 や不良造形品などをぺレット状に裁断し，再生機に投入 することを想定しているが，本研究では再生によるフィ ラメントの物性変化を評価するため, 予備検討としてフ イラメント状態のまま裁断したものをペレットとして再 生機に投入した。フィラメントの再生は, 再生機の設定 温度を $150^{\circ} \mathrm{C}$, 吐出速度約 $42 \mathrm{~mm} / \mathrm{s}(2.5 \mathrm{~m} / \mathrm{min})$ で行 った。この温度は PP の造形温度より低いが，これは温 度計測点が再生機の吐出ノズル部先端付近にあったため であり，ノズル内部の実質温度は PP の造形温度に近い $200^{\circ} \mathrm{C}$ 前後になっていると思われる.

Fig. 2 に未再生および再生処理後の PP 単体および $\mathrm{PP} / \mathrm{CF}$ フィラメントの外観写真を示す。また, Fig. 3 に $\mathrm{PP} / \mathrm{CF}$ フィラメントの長手方向断面の顕微鏡写真を示 す。本研究で用いたフィラメント再生機では，押し出し 直後に自重によるテンションがかかりフィラメントがわ 


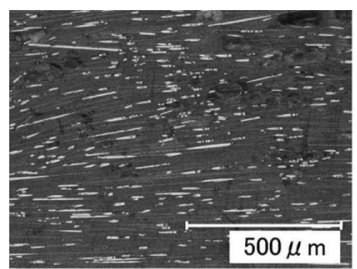

(a) Blank

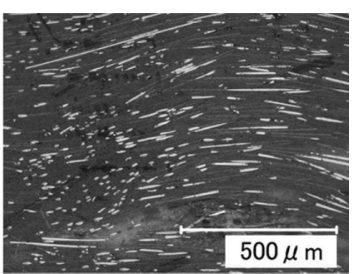

(b) 1 time reproduction
Fig. 3 Microscope photographs of blank and reproduced $\mathrm{PP} / \mathrm{CF}$.

Table 1 Fiber count of blank and reproduced PP/ CF filaments.

\begin{tabular}{cc}
\hline \hline Number of reproduction & Fiber count \\
\hline Blank & 6,564 \\
1 time & 6,934 \\
2 times & 8,451 \\
3 times & 10,819 \\
\hline
\end{tabular}

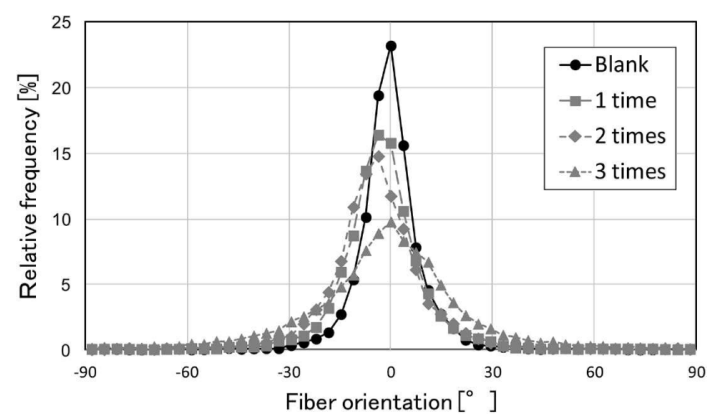

Fig. 4 Distribution of fiber orientation contained in blank and reproduced $\mathrm{PP} / \mathrm{CF}$ filaments.

ずかに細くなるため, 初期フィラメントの直径 $1.75 \mathrm{~mm}$ より太い穴径 $3 \mathrm{~mm}$ のノズルを用いた。このため, 再生 後のフィラメントはやや太くなっており, 長手方向に直 径の摇らぎが観察できた。また, 顕微鏡画像より, 最大 繊維長は約 $500 \mu \mathrm{m}$ であることが観察できた。さらに, 初 期フィラメントでは炭素繊維の多くがフィラメント長手 方向に配列しているのに対し，再生後は繊維配向に乱れ が観察された。顕微鏡写真から表面露出繊維の面積率を

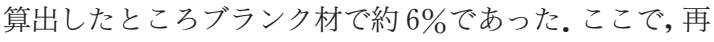
生処理による繊維数や繊維配向の変化傾向を調査するた めに，画像解析により未再生，1３回再生の繊維状態を 調べた結果を Table 1 および Fig. 4 に示す. 画像解析に は Image-J を用い，300 倍の顕微鏡写真から $1.11 \times 0.68$ $\mathrm{mm}$ の領域 30 枚を抽出して分析した。な抢, 瀻維形状は 楕円形状で近似している. Table 1 から, 再生処理による

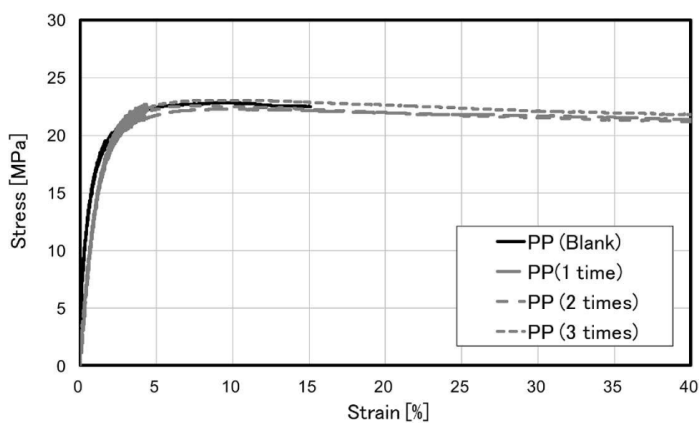

Fig. 5 Comparison of stress-strain diagram between blank and reproduced PP filaments.

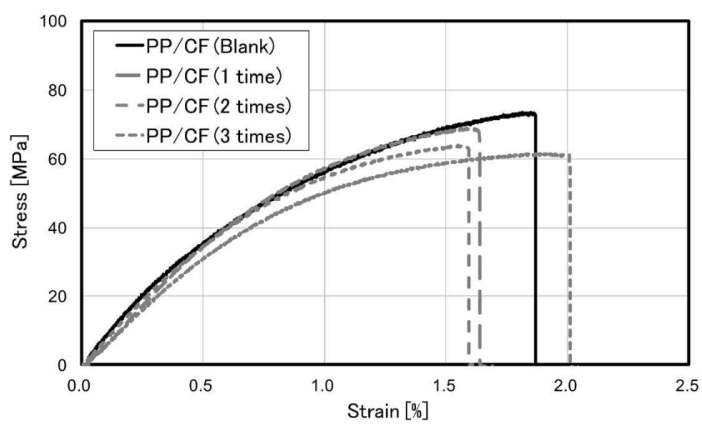

Fig. 6 Comparison of stress-strain diagram between blank and reproduced $\mathrm{PP} / \mathrm{CF}$ filaments.

繊維数の増加傾向がみられる. 瀻維数の増加要因には, 繊維配向がフィラメント軸から傾いたことによる観察断 面への出現確率の増加も考えられるが, 再生処理過程で 繊維が裁断された可能性もある. Fig. 4 では 1 回再生と 2 回再生で繊維配向角分布が同等なことから繊維配向の 乱れによる纎維数増加は同程度であると判断できる。し かし, 1 回再生よりも 2 回再生で緘維数の明らかな増加 がみられることから, 再生回数に応じた纎維破断が生じ ていると考吕れる.

\section{3 再生フィラメントのカ学特性評価}

フィラメントの再生処理による力学特性変化を調査す るため, 引張試験機（島津製作所, AG-X Plus $100 \mathrm{kN}$ ) を用いてフィラメントの引張試験を行った。評点間距離 は $60 \mathrm{~mm}$, 引張速度 $10 \mathrm{~mm} / \mathrm{min}$ とし, 各条件について 5 本試験を行った. Fig. 5, 6 に PP 単体および $\mathrm{PP} / \mathrm{CF}$ フィラメントの再生による応力ーひずみ線図の変化を示 す. PP 単体では $40 \%$ ひずみでも破断せず，延性的な性 質を示したが，PP/CF ではヤング率が 4 倍以上に向上 し，破断ひずみの低下がみられたことから炭素繊維含有 


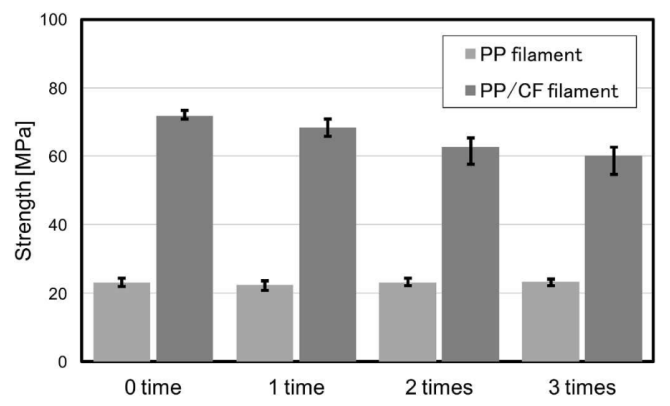

Fig. 7 Comparison of tensile strength between blank and reproduced $\mathrm{PP} / \mathrm{CF}$ filaments.

の効果が確認できた。一方，強度を比較した Fig. 7 を みると, PP 単体では再生による強度の変化は少なかっ たが，PP/CFでは再生を重ねるごとに強度が低下する

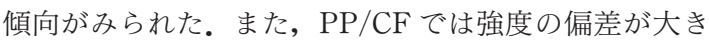
く, 再生回数の増加につれて偏差が増加する傾向がみら れた。これらは, 再生処理により, 䌩維配向の乱れや繊 維長の減少が生じたことが要因と考えられる。

\section{3. 再生フィラメントの超音波検査}

\section{1 フィラメント検査装置の概要}

本研究で設計製作したフィラメント検查装置の外観写 真を Fig. 8 亿，概略図を Fig. 9 亿示す。本装置は，フィ ラメントスプール保持部，超音波検査部，フィラメント 自動送り装置で構成されている。検查部には超音波探触 子を 2 つ設置し，一方を発信側，他方を受信側としてフ イラメント長手方向に伝播する超音波を送受信する透過 法を採用した。連続検查時に使用する自動送り装置には ステッピングモータを用いている。この自動送り装置の 精度検証を行った結果，ウレタン製ローラのひずみが原 因とみられる誤差が生じたが，最大でも $1 \%$ 以下である ことを確認した。

フィラメントの連続検査を実施する際，超音波探触子 とフィラメントの間に摩擦が生じるため, 探触子の摩耗 損傷を防ぐ必要がある。また，接触面積の大きな探触子 を用いると超音波伝播距離が不明確になり，伝播速度計 測の精度低下につながる。そこで，探触子前面にアクリ ルウェッジを取り付けることを検討した。Fig. 10 亿検 討したウェッジの断面形状を示す. 幅 $w=18 \mathrm{~mm}$, 高さ $h=10 \mathrm{~mm}$ に統一し,台形ウェッジ, ステップウェッジで は, フィラメントとの接触幅 $b$ を $1 \mathrm{~mm}, 2.0 \mathrm{~mm}, 2.5$ $\mathrm{mm}, 3 \mathrm{~mm}, 4 \mathrm{~mm}, 5 \mathrm{~mm}$ について受信波形を比較した。 Fig. 11 に代表的な受信波形を示す. 本研究では，先頭波

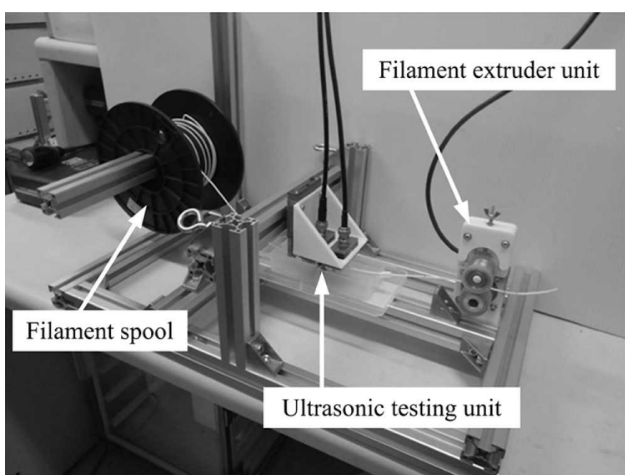

Fig. 8 Overview of the developed ultrasonic tester.

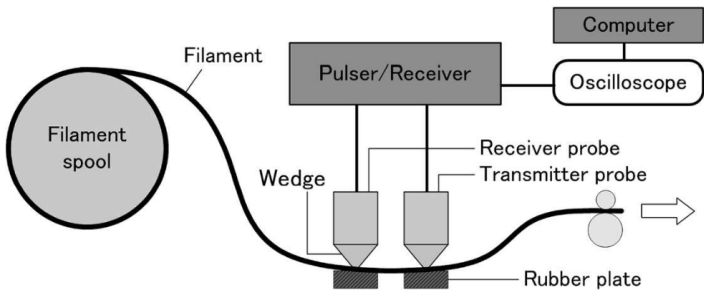

Fig. 9 Simplified illustration of ultrasonic tester.

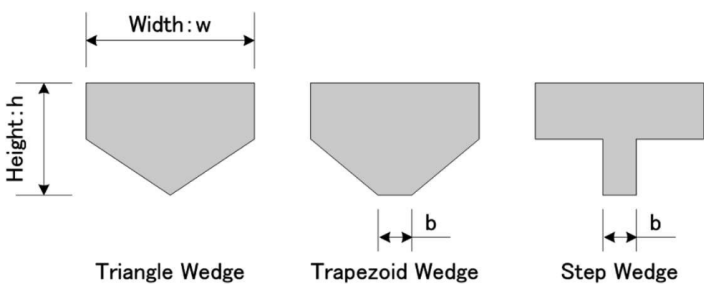

Fig. 10 Cross-sectional view of the wedges.

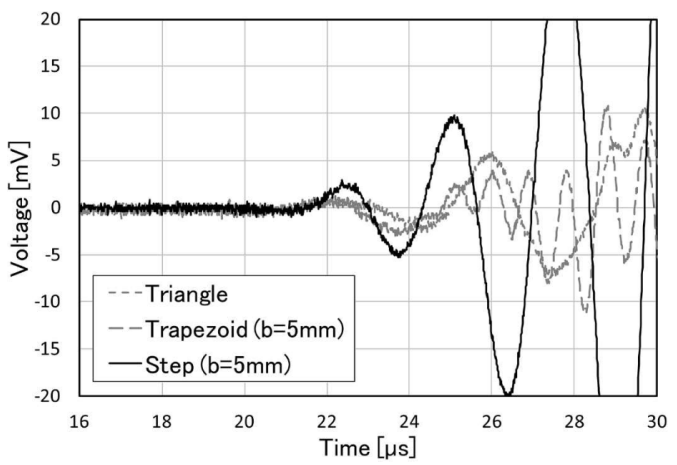

Fig. 11 Comparison of waveform with different wedges. 


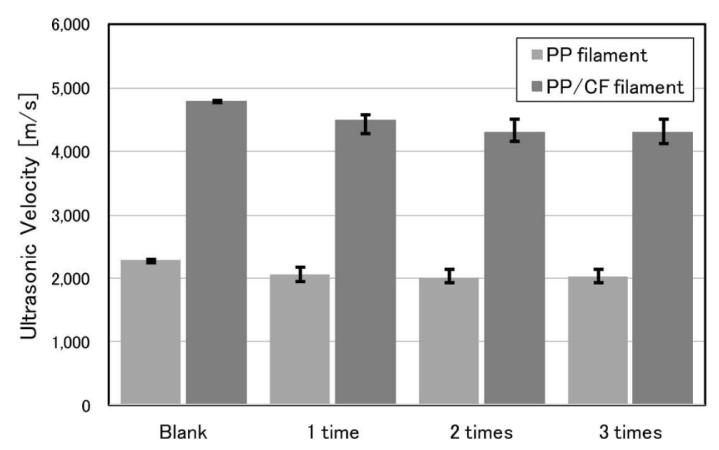

Fig. 12 Comparison of ultrasonic velocities of $\mathrm{PP}$ and $\mathrm{PP} / \mathrm{CF}$ filaments.

形の伝播速度を計測対象としているため，先頭領域での 波形安定性が求められる.グラフより，ステップウェッ ジが最も信号強度が大きく安定した受信波形となってい ることがわかる、ステップウェッジの接触幅による波形 比較を行った結果, $5 \mathrm{~mm}$ 幅のウェッジが最も良好な波 形の取得ができた。そこで，以下の実験では $5 \mathrm{~mm}$ 幅の ステップウェッジを用いて超音波計測を行った。

\section{2 超音波伝播速度の測定}

$\mathrm{PP}$ 単体および $\mathrm{PP} / \mathrm{CF}$ フィラメントについて, 未再 生と $1 \sim 3$ 回再生のフィラメントを用意し, 超音波測定 を行った。本実験には, Fig. 8 の検査装置とは別の簡易 計測装置を用いた. 入力波は $1 \mathrm{MHz}, 400 \mathrm{~V}$ のスクエア パルスとし，伝播距離（送受信探触子中心間の距離）を 23〜28 mm において $0.5 \mathrm{~mm}$ 間隔で変化させて波形を取 得し, 各波形の先頭領域のゼロクロス点を伝播時間とし て計測した。超音波伝播速度は（伝播距離）vs.（伝播時 間) 線図の傾きから算出した. Fig. 12 に伝播速度の比較 を示す.いずれのフィラメントも再生により伝播速度の 低下がみられ, $\mathrm{PP}$ 単体に比べ $\mathrm{PP} / \mathrm{CF}$ の伝播速度低下 が大きくなっている.また, 再生処理により, PP 単体に 比べて $\mathrm{PP} / \mathrm{CF}$ の速度のばらつきが大きくなる傾向がみ られ, Fig. 7 の引張試験結果に対応している.これらの ことから, $\mathrm{PP} / \mathrm{CF}$ では繊維配向乱れや繊維密度の摇ら ぎが検出されている可能性が考えられる.

\subsection{FDTD シミュレーションによる波動伝播解析}

Fig. 2 で示したように, 再生フィラメントは初期フィ ラメントに比べて直径の摇らぎが大きくなる傾向にあ る.このため, Fig. 12 でみられた超音波伝播速度の変化 は, この形状変化の影響を受けている可能性がある. そ こで, FDTD 法 ${ }^{5)}$ にる超音波伝播シミュレーションを 行い, 形状変化が超音波計測に与える影響を評価した。
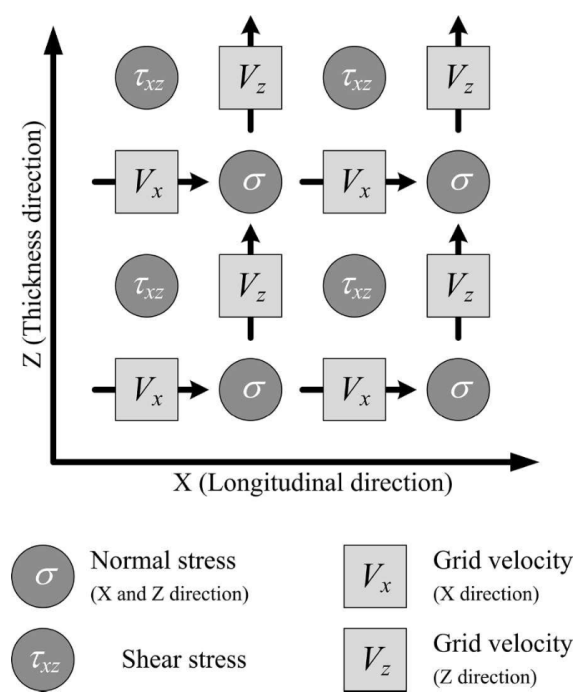

Fig. 13 Diagram of 2-D staggered grid system in $x-z$ plane.

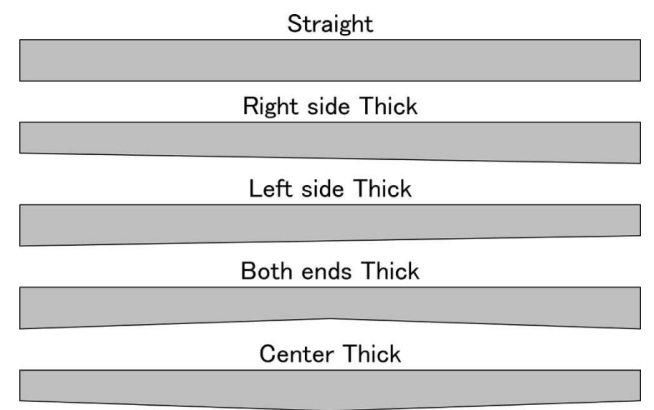

Fig. 14 Filament shape along the longitudinal direction.

FDTD 法は差分法の一種であり, 材料密度 $\rho$, 材料剛性 $C$, 粒子変位 $u$ の関係式として式(1)で表される波動方 程式を粒子速度 $v=\partial u / \partial t$ として展開した式(2)を基本 式としている. Fig. 13 に示した格子モデルにおいて, 粒 子速度 $v$ と応力 $T$ の差分式を交互に計算することで, 弾性波の時間的進展を計算する.

$$
\begin{gathered}
\rho \frac{\partial^{2} u}{\partial t^{2}}=C \frac{\partial^{2} u}{\partial x^{2}} \\
\rho \frac{\partial v}{\partial t}=\frac{\partial T}{\partial x}, \quad \frac{\partial T}{\partial t}=C \frac{\partial v}{\partial x}
\end{gathered}
$$

シミュレーションでは, 長手方向の形状変化が Fig. 14 に示す 5 種類のフィラメントについて検討した.なお, 全ての形状において最大傾斜は約 $5 \%$ となるように設定 し, 超音波伝播距離を $25 \mathrm{~mm}$, 空間分割幅を $40 \mu \mathrm{m}$, 時 間分割幅を $20 \mathrm{~ns}$ として 2 次元解析を行った. シミュレ 


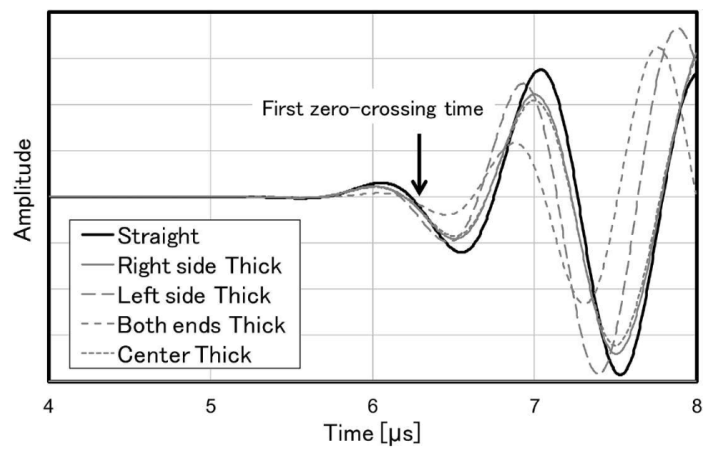

Fig. 15 Comparison of waveforms for different filament shapes.

Table 2 Wave arrival times with different filament shapes.

\begin{tabular}{lc}
\hline \hline Filament shape & Arrival time $[\mu \mathrm{s}]$ \\
\hline Straight & 6.23 \\
Right side thick & 6.20 \\
Left side thick & 6.18 \\
Both ends thick & 6.19 \\
Center thick & 6.20 \\
\hline
\end{tabular}

ーション波形の比較を Fig. 15 に示す.また，算出され た波形から先頭波形のゼロクロスポイントを読み取って 算出した到達時間を Table 2 亿示す。表より，ストレー ト形状との差は最大でも $1 \%$ 未満であり, フィラメント の形状変化が超音波伝播速度に与える影響は小さいこと が確認できた。よって, 前節で得られた超音波伝播速度 の変化は, フィラメントの形状変化によるものではな く，再生によるフィラメントの物性変化を反映したもの と考えられる。

\section{4. 赤池情報量基準による検査精度改善}

前章では簡易計測装置を用い，送受信探触子間の距離 を変化させて超音波伝播速度の計測を行ったが, Fig. 8 に示す実際の検查装置では，送受信探触子間の距離を固 定して取得した個別の検查波形に対して波形到達時間を 判定し伝播速度を算出する必要がある。しかし, フィラ メントを伝播した超音波は微弱であるため, 波形到達時 間の判定ミスが懸念される. 波形到達時間の判定法とし ては，電圧に閾值を設定する閾值法がある。この方法で は，設定された閾值を超える信号が検出された時間以降 で最初に現れるゼロクロス点を検出するが，微弱な信号 の場合は，ノイズの影響を受けて検出点が摇らぐ可能性 がある、そこで本研究では, 統計デー夕処理に用いられ

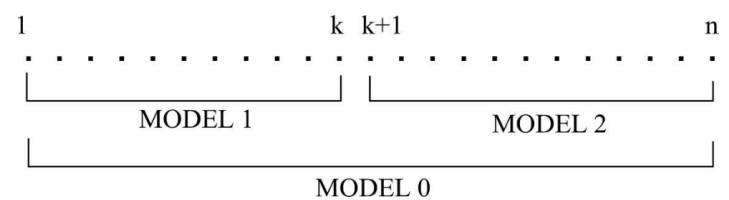

Fig. 16 Illustration of the method to divide a section.

る赤池情報量基準 (AIC: Akaike information criterion) に基づく波形到達時間の判定を試みた。

波形データの先頭位置を決めることは波形デー夕をノ イズ部と波形部に分ける分割点を求めることに相当す る. 本研究ではこの区間分割の判断基準として次式で定 義される赤池情報量基準 ${ }^{6}$ を用いる。

$$
\begin{aligned}
A I C= & -2\{(\text { モデルの最大対数尤度 }) \\
& -(\text { モデルの自由パラメータの数 })\}
\end{aligned}
$$

AIC は実際の分布とモデル分布の適合度を評価する 基準である。一般にモデルの対数尤度が大きいほど真の 分布に近いとされる。パラメー夕数を増やすほど対数尤 度が大きくなるため式(3)に拈ける第 1 項は負の方向に 大きくなる。一方第 2 項はパラメー夕数そのものである ためパラメー夕数を増やすほど大きくなる。つまり AIC の值を小さくすることは, パラメー夕数を極力小さく保 ちながらモデル分布を真の分布に近づけることに相当 し，AICを最小にするモデルを最適とみなす。

本研究では測定信号のノイズ部と波形本体部が異なる 統計分布特性を持つことに着目した。ある時間でデー夕 を 2 つに分割し，各区間の時間ごとの振幅を離散化して カウントしてヒストグラムに変換する。その後，その分 布特性がモデル分布とどれだけ近いかを評価する，区間 分割は次の手順で行う。

(1) Fig. 16 のように $n$ 個の点を 2 つに分け，区間 1(1 $k)$ KODEL 1 ，区間 $2(k+1 \sim n)$ そ MODEL 2 を 最尤法によりあてはめ,このときの AIC を計算する (AIC $(k)$ と記す)。

(2) 分割点を移動させながら AIC を計算し, $A I C(k)$ を 最小にする点 $k_{\min }$ を探し, $k_{\min }$ を分割点つまり波形到 達時間とする。

ここでは測定より得られた波形データのモデルとして, 正規分布モデルを用いた。正規分布モデルを用いた $A I C(k)$ は次式で表される7).

$$
\begin{aligned}
\operatorname{AIC}(k)= & n \log 2 \pi+k \log \sigma_{1}^{2} \\
& +(n-k) \log \sigma_{2}^{2}+n+2 \times 4
\end{aligned}
$$




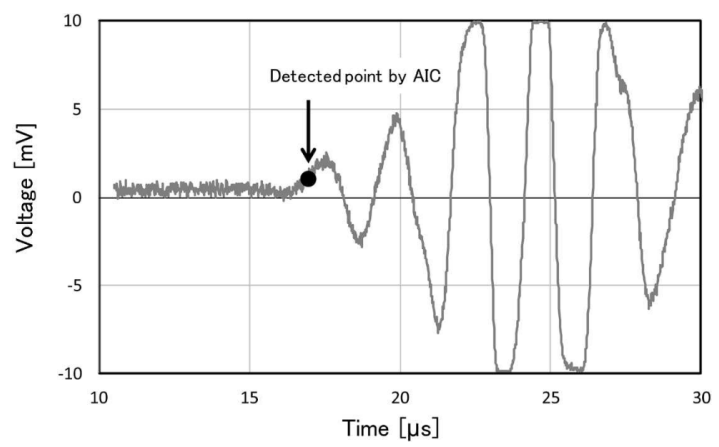

Fig. 17 Example waveform and wave arrival time detected by AIC method.

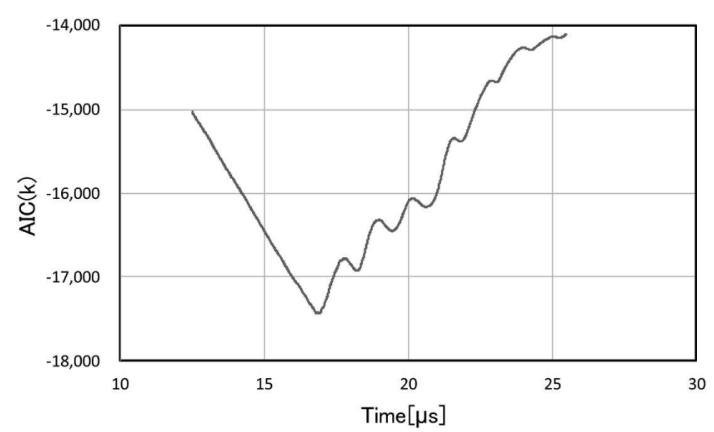

Fig. 18 Variation of AIC value around the wave arrival time.

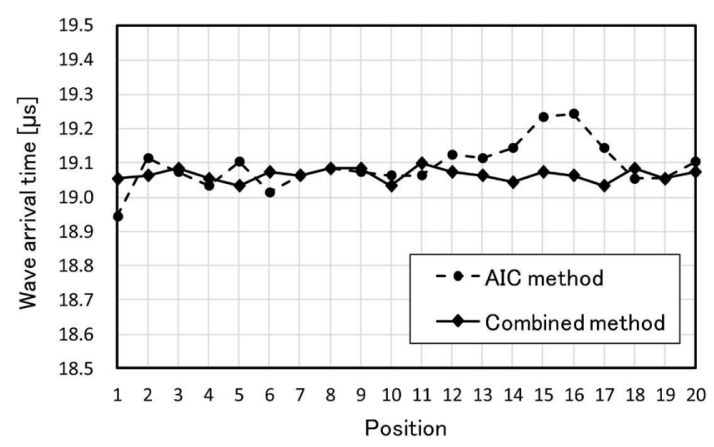

Fig. 19 Comparison of wave arrival times between AIC method and combined method.

ここで， $\sigma_{1}^{2} ， \sigma_{2}^{2}$ はそれぞれ区間 1 , 区間 2 に正規分布モ デルをあてはめた時の分散である，以下ではこの区間分 割法を受信波の波形到達時間の読み取りに使用した。

Fig. 17 に波形到達時間の読み取りを行った波形および $\mathrm{AIC}$ に基づく波形到達時間の検出点の一例を示す。ま た, Fig. 18 に式(4)により算出した各分割点での $A I C(k)$
の計算值をグラフ化したものを示す. Fig. 18 より, AIC (k) が最小值を示す時間が先頭波形領域のゼロクロス点 付近に対応していることが確認できる。

以上より，AIC を適用することで数学的客観性を保持 した波形到達時間の読み取りが可能であることがわかつ た。しかし, AIC 法による検出点は, 必ずしも波形先頭 領域のゼロクロス点に対応するわけではない.そこで, AIC 法で検出された時間を基準時間として，その周辺を 3 次曲線近似した波形を用いてゼロクロス点を検出する 複合手法の適用を検討した. Fig. 19 に AIC 法および $\mathrm{AIC}$ 法と閾值法の複合基準による波形到達時間の検出 結果の比較を示す. Fig. 19 より，複合基準を用いること でより安定した波形到達時間の検出が可能であることが 確認できた。

\section{5. 結言}

本研究では $3 \mathrm{D}$ プリンタ用フィラメントの再生による 劣化特性を明らかにするとともに，再生フィラメントの 超音波による物性評価法について検討した。 以下に得ら れた結論を示す。

(1) PP 単体フィラメントおよび PP に炭素短繊維を含 有させた $\mathrm{PP} / \mathrm{CF}$ フィラメントは, 再生処理により強 度が低下する傾向がみられた. 特に, $\mathrm{PP} / \mathrm{CF}$ フィラメ ントでは繊維の裁断や配向乱れに伴う劣化が観察され た.

（2）FDTDによる波動伝播シミュレーションにより，フ イラメント形状が超音波伝播に与える影響を評価した 結果，フィラメント形状の変化は受信波強度に影響を 与えるが，超音波伝播速度に与える影響は小さいこと がわかった。

(3) $\mathrm{PP}$ 単体フィラメントおよび $\mathrm{PP} / \mathrm{CF}$ フィラメント の再生前後において, 超音波検査を行ったところ, 再 生回数の増加に伴い超音波伝播速度の低下がみられ, 超音波測定によりフィラメントの劣化状態の把握が可 能であることがわかった。

（4）赤池情報量基準 (AIC) を用いることで波形到達時間 の判定が可能であることを確認した.また， AIC 法に よる検出時間を基準として閾值法を適用することで, より安定した波形到達時間の検出が可能であることが わかった。

本研究では, 超音波伝播速度を評価指標としてフィラ メントの劣化評価を行ったため, 初期フィラメントの超 音波伝播速度が不明の場合は適用できない.また, PP フ イラメントと $\mathrm{PP} / \mathrm{CF}$ フィラメントを混合して再生した 
フィラメントでは繊維含有率が変化するため, 劣化を判 断できない. しかし，混合フィラメントにおいては，超 音波伝播速度が繊維含有率の目安となることから, 再生 フィラメントの品質保証への適用は可能と考えられる.

本研究の一部は「高専-長岡技科大共同研究助成」の支 援を受けて行った.ここに謝意を表する。

\section{参 考 文 献}

1) 太田崇文, 岡田耕治, 齊藤 梓, 吉田一也, 村澤 剛, 川上 勝, 古川英光：日本機械学会論文集， 83,850 (2017), 16-00567.

2) F. van der Klift, Y. Koga, A. Todoroki, M. Ueda,
Y. Hirano \& R. Matsuzaki : Open J. Comp. Mater., 6 (2016), 18-27.

3) R. Matsuzaki, M. Ueda, M. Namiki, T. Jeong, H. Asahara, K. Horiguchi, T. Nakamura, A. Todoroki \& Y. Hirano: Sci. Rep., 6 (2016), Article number: 23058 .

4）山脇正雄, 河野洋輔：日本複合材料学会誌, 43,3 (2017), 97-103.

5) 佐藤雅弘：FDTD 法による弾性振動・波動の解析入 門, 森北出版 (2003).

6) H. Akaike: 2nd International Symposium on Information Theory, ed. by B.N. Petrov \& F. Csaki, Akademiai Kiado, Budapest (1973), pp. 267-281.

7）前田直樹：地震第 2 輯, 38 (1985)，365-379. 